\title{
Nassarius foveolatus (Gastropoda, Nassariidae), a new record of an exotic species in Brazil
}

\author{
Marcos de Vasconcellos Gernet ${ }^{1,6}$; Carlos Eduardo Belz ${ }^{1,7}$; Rafael Antunes Baggio ${ }^{2}$; Carlos João Birckolz ${ }^{1,8}$; \\ Elizângela da Veiga Santos ${ }^{1,3}$; Luiz Ricardo L. Simone ${ }^{4,9}$; Daniel Abbate ${ }^{4,10}$ \& Rafael Metri ${ }^{5}$ \\ ${ }^{1}$ Universidade Federal do Paraná (UFPR), Centro de Estudos do Mar (CEM), Laboratório de Ecologia Aplicada e Bioinvasões (LEBIO). \\ Pontal do Paraná, PR, Brasil. \\ 2 Universidade Federal do Paraná (UFPR), Departamento de Zoologia (DZO0), Laboratório de Ecologia Molecular e Parasitologia Evolutiva (LEMPE). \\ Curitiba, PR, Brasil. ORCID: http://orcid.org/0000-0001-8307-1426. E-mail: rbaggio@ufpr.br \\ 3 Universidade Federal do Paraná (UFPR), Setor Litoral. Matinhos, PR, Brasil. ORCID: http://orcid.org/0000-0001-9834-8379. \\ E-mail: lizveiga.ga@gmail.com \\ ${ }^{4}$ Universidade de São Paulo (USP), Museu de Zoologia (MZUSP). São Paulo, SP, Brasil. \\ ${ }^{5}$ Universidade Estadual do Paraná (UNESPAR). Paranaguá, PR, Brasil. ORCID: http://orcid.org/0000-0002-1502-0720. E-mail: rmetri@gmail.com \\ ${ }^{6}$ ORCID: http://orcid.org/0000-0001-5116-5719. E-mail:Imvgernet@gmail.com (corresponding author) \\ ${ }^{7}$ ORCID: http://orcid.org/0000-0002-2381-8185. E-mail: belzoceanos@gmail.com \\ ${ }^{8}$ ORCID: http://orcid.org/0000-0002-7896-1018. E-mail: carlosbirc@gmail.com \\ ${ }^{9}$ ORCID: http://orcid.org/0000-0002-1397-9823. E-mail: Irsimone@usp.br \\ ${ }^{10}$ ORCID: http://orcid.org/0000-0002-6460-9224. E-mail: danielabbate@usp.br
}

\begin{abstract}
Exotic species are those that occur in an area beyond their natural limit and they are considered invasive when they cause harm to the economy, environment, or human health. In coastal environments, ballast water and inlays on the hull and other parts of vessels are the main ways of introducing invasive aquatic alien species. Nassarius foveolatus (Dunker, 1847) is native from the Central and East Indian Ocean to the East China Sea. The first specimens (empty shells) of $N$. foveolatus were collected manually on November 11, 2017 on the Rocio footbridge, located in the Paranaguá Estuarine Complex, on the coast of the State of Paraná, southern Brazil. Posteriorly, live specimens were collected in other localities of this bay. It is already possible to infer that the specimens of $N$. foveolatus occur together with the native specimens of $N$. vibex (Say, 1822), having the same niche. As previously only N. vibex existed in that place, at least a displacement of this native species has been occurred. However, certainly future ecological studies may confirm this displacement and additional consequences to the local ecosystem, as nassariids can be predators and scavengers. Control procedures should be also greatly implemented.
\end{abstract}

Key-Words. Invasive; Exotic; Mollusca; Nassarius foveolatus; Paraná coast.

\section{INTRODUCTION}

Exotic, non-native or introduced species are those that occur in an area beyond their natural limit and they are considered invasive when they cause harm to the economy, environment, or human health (Carlton, 1996). Bioinvasions, i.e., the introduction of alien species into different ecosystems, are the major causes of biodiversity loss in the world, causing damage to local species and to the functioning of ecosystems (Stachowicz et al., 1999; Silva \& Barros, 2011).

In coastal environments, ballast water (with sediments) and inlays on the hull and other parts of vessels are the main ways of introducing invasive aquatic alien species (Ferreira et al., 2004). Ballast water introduces aquatic organisms that are harmful to the environmental balance (in- cluding bacteria and viruses), both in marine and freshwater ecosystems, degrading important commercial activities such as those associated with fishing (Souza et al., 2009).

Nassariidae is a family of almost exclusively marine detritivores snails inhabiting bottoms of unconsolidated substrates and, to a lesser extent, rocky shores in tropical waters, with greater abundance between 0 and $300 \mathrm{~m}$ deep (Nekhaev, 2014). This group belongs to the neogastropod superfamily Buccinoidea and consists of more than 400 species (Brown, 1982; Galindo et al., 2016) divided into 18 extant genera, of which Buccinanops d'Orbigny, 1841 and Nassarius Duméril, 1805, are the largest genera in the family currently represented in the Brazilian coast (Rios, 2009; Rosenberg, 2009). In Brazilian waters, nine species of Nassarius have been recorded (Abbate \& Cavallari, 2013). 
The typical shells of the family Nassariidae are characterized as being small to medium, with short and curved siphonal canal, conical protoconch, and horny operculum (Rios, 2009). It presents a high shell spire, oval shape with or without shoulder in the opening. The surface of the shell may be smooth or may exhibit axial and spiral sculptures (Abbate \& Cavallari, 2013; Rios, 2009). Most nassariids have a well-developed callus. It has a rich fossil record dated since the Late Cretaceous (Taylor et al., 1980; Van Dingenen et al., 2015; Galindo et al., 2016).

The genus Nassarius and its close relatives tend to be restricted to muddy environments, though a few species shelter among loose rocks and sand. Ecologically, most species of Nassarius are thought to be facultative scavengers inhabiting inter- to subtidal shallow marine environments. As scavengers, they are important in maintaining the balance of ecological systems, especially for the benthic community (Cernohorsky, 1984). Their taxonomy, especially the status of the alleged genera and subgenera, is still far from a resolution and the distribution of most species is poorly understood (Cavallari \& Abbate, 2013; Galindo et al., 2016). Compared to other gastropods, Nassarius snails have a relatively long planktonic larval phase, leading to a high level of dispersal capacity by marine currents (Tallmark, 1980). They can also be transported by ballast water and oysters farming to other environments and, by surviving, consequently becoming exotic species (e.g., Carlton, 1992; Bachelet et al., 2004; Townsend et al., 2010; Fofonoff et al., 2018; Goka, 2019).

Nassarius foveolatus (Dunker, 1847) is native from Central and East Indian Ocean to East China Sea, including countries as Mauritius, Pakistan, India, Myanmar, Thailand, Singapore, Malaysia and China (Cernohorsky, 1984; Subba Rao et al., 1992; Raut et al., 2005; Rosenberg, 2006; Robba et al., 2007; Tan \& Woo, 2010; Zhang \& Yang, 2010; Mahapatro et al., 2018). It presents a small, oval, slightly striated shell with furrowed suture, columella with slight callosity, denticulate external lip, and long and narrow feet.

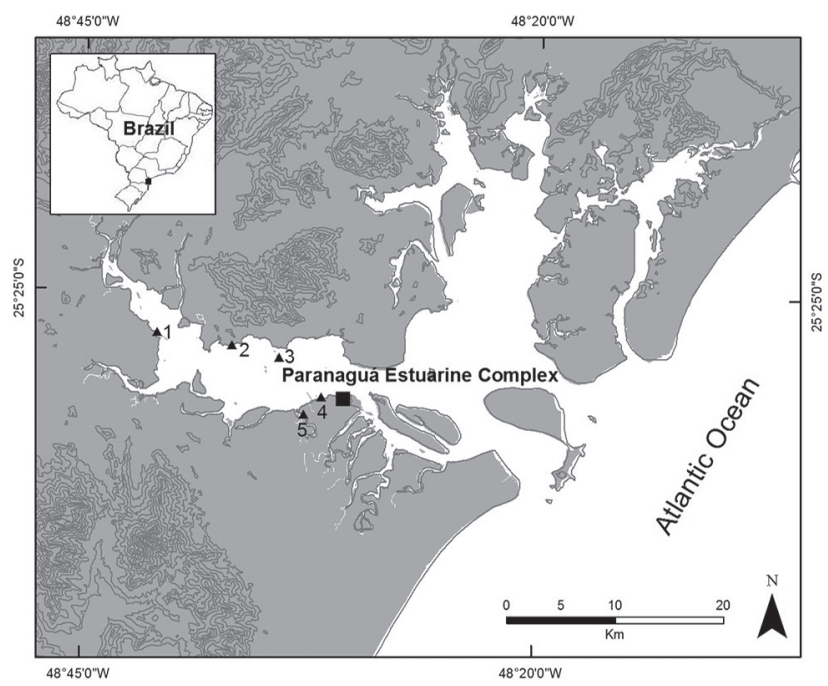

Figure 1. Paranaguá Estuarine Complex and sites where Nassarius foveolatus was found. Black square $=$ Port of Paranaguá; $1=$ Ponta da Pita; $2=$ Europinha; 3 = Lamin Island; 4 = Rocio; 5 = Emboguaçu River.

The aim of this study is to report the first occurrence of the exotic species $N$. foveolatus in Brazil, confirmed both by morphological and molecular approaches. A discussion on its possible via of transportation and environmental consequences is also included.

\section{MATERIAL AND METHODS}

The first specimens (empty shells) of an unknown Nassarius species were collected manually on November 11, 2017, on the Rocio footbridge (2530.236'S $\left.48^{\circ} 31.891^{\prime} \mathrm{W}\right)$, located in the Paranaguá Estuarine Complex, on the coast of the state of Paraná, southern Brazil (Fig. 1). Subsequently, on December 17, 2017, live specimens were collected in the same locality. The material collected was deposited in the molluscan collections of the Museu de Zoologia da Universidade de São Paulo,

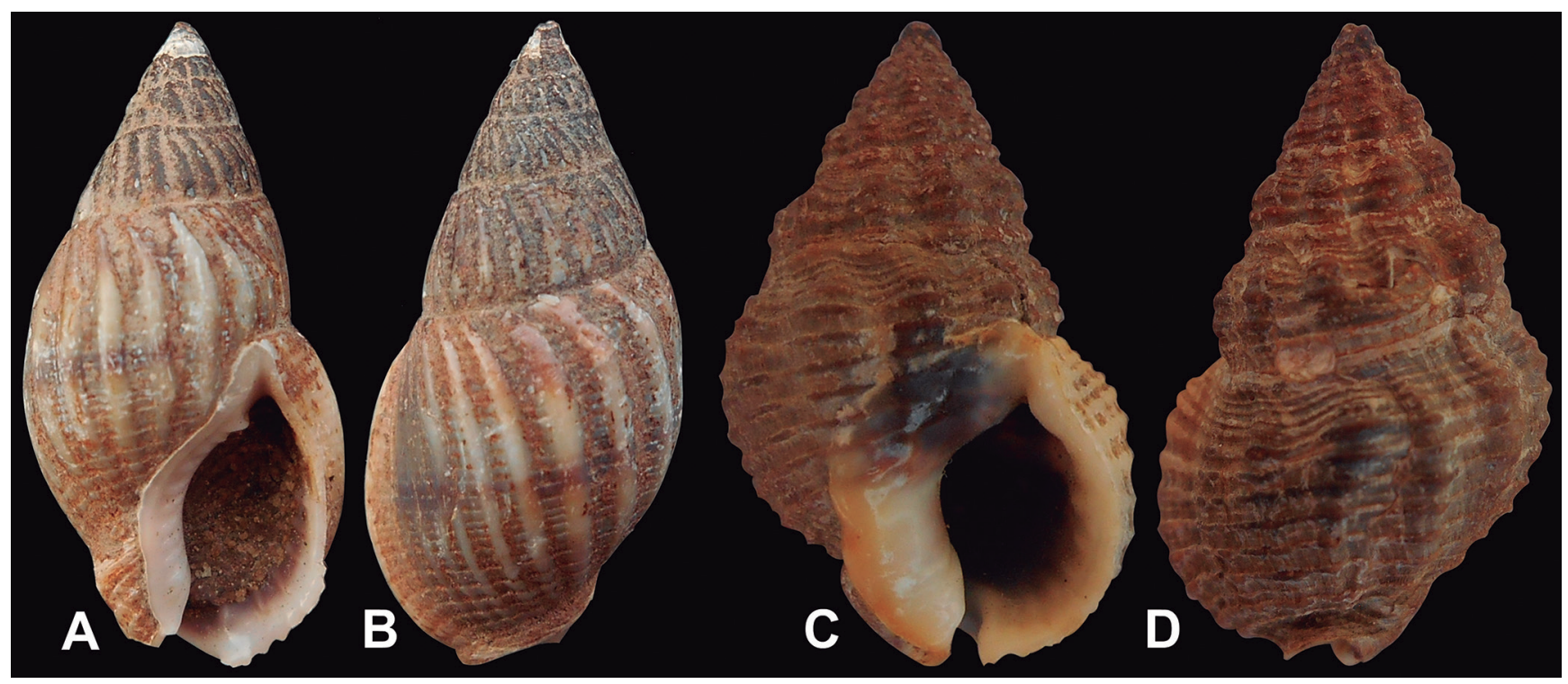

Figure 2. Shells of Nassarius found in Paranaguá Estuarine Complex. H: Shell height; D: shell greatest diameter. (A) Ventral view of N. foveolatus; (B) Dorsal view of N. foveolatus; (A-B) LEBI0 577 \#2; H=17.2 mm; D = $9.4 \mathrm{~mm}$. (C) Ventral view of N. vibex; (D) Dorsal view of N. vibex; (C-D) LEBI0 347; H=18.6 mm; D = 14.7 mm. 
São Paulo, Brazil (MZUSP 136955, 3 spm.; MZUSP 143545, 11 spm.; MZUSP 143546, 20 spm.; MZUSP 143617, 14 spm.; MZUSP 143618, 16 spm.) and at the Laboratório de Ecologia Aplicada e Bioinvasões, Pontal do Paraná, Brazil (LEBIO 577, 9 spm.; LEBIO 578, 6 spm.).

The morphological identification was done according to Cernohorsky (1984). To confirm the morphological identification, molecular identification was performed using the DNA Barcode method (Hebert et al., 2003). Firstly, the genomic DNA was extracted using the EZ-DNA kit (Biological Industries) from muscle. Then, a fragment of $650 \mathrm{bp}$ of the cytochrome oxidase subunit 1 (COI) was sequenced. The amplification comprises a PCR with 25 ul final concentrations of $2.5 x$ buffer, $3 \mathrm{mM}$ of $\mathrm{MgCl} 2,0.4 \mathrm{uM}$ of dNTP, 0.1 pmol of each HCO and LCO (Folmer et al., 1994), 0.1 U of Taq Polymerase and 50 ng of DNA template. PCR product was purified using PEG 8000 (Amresco Inc., Cleveland, OH, USA). The sequencing reactions were performed with BigDye ${ }^{\circledR}$ kit
(Applied Biosystems) according the manufacturer protocol and was purified with Sephadex G-50 (GE Healthcare Bio-Sciences AB, Uppsala, Sweden). The final product was sequenced in an ABI 3130 Genetic Analyzer (Applied Biosystems).

The identification was confirmed though NeighborJoining (NJ) and Bayesian (BI) trees. Sequences of Nassarius spp. accessed from GenBank (see species and accession number in Table 1) were used as reference sequences and Antillophos sp. (GU393391.1) was used as outgroup. Sequences were aligned using the Muscle Algorithm (Edgar, 2004) in Geneious 2019.1.1. The NJ was constructed in Geneious, using the Tamura-Nei evolution model (Tamura \& Nei, 1993) and 10 thousand bootstraps. The $\mathrm{BI}$ tree was constructed in the Beast 1.8 (Drummond et al., 2012), with three independent runs of 100 million MCMC generations sampled each 10,000 trees, $10 \%$ of burn-in and substitution model indicated by jModeltest 2.1.10 (Darriba et al., 2012).

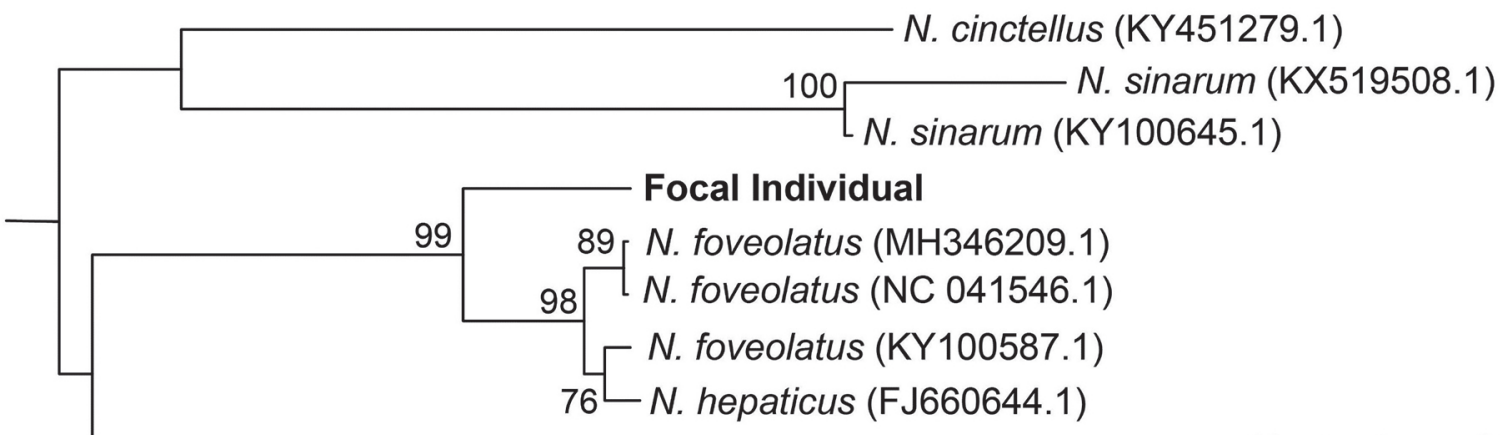

N. concinnus (KY451364.1)

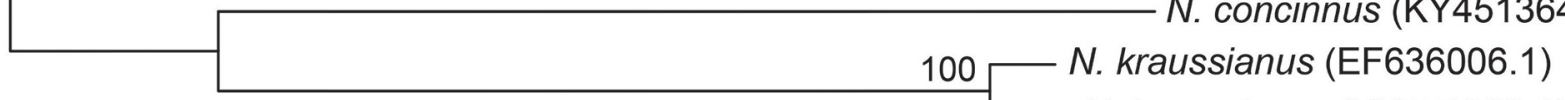
N. kraussianus (KY451322.1)

\section{A $\quad 0.02$}

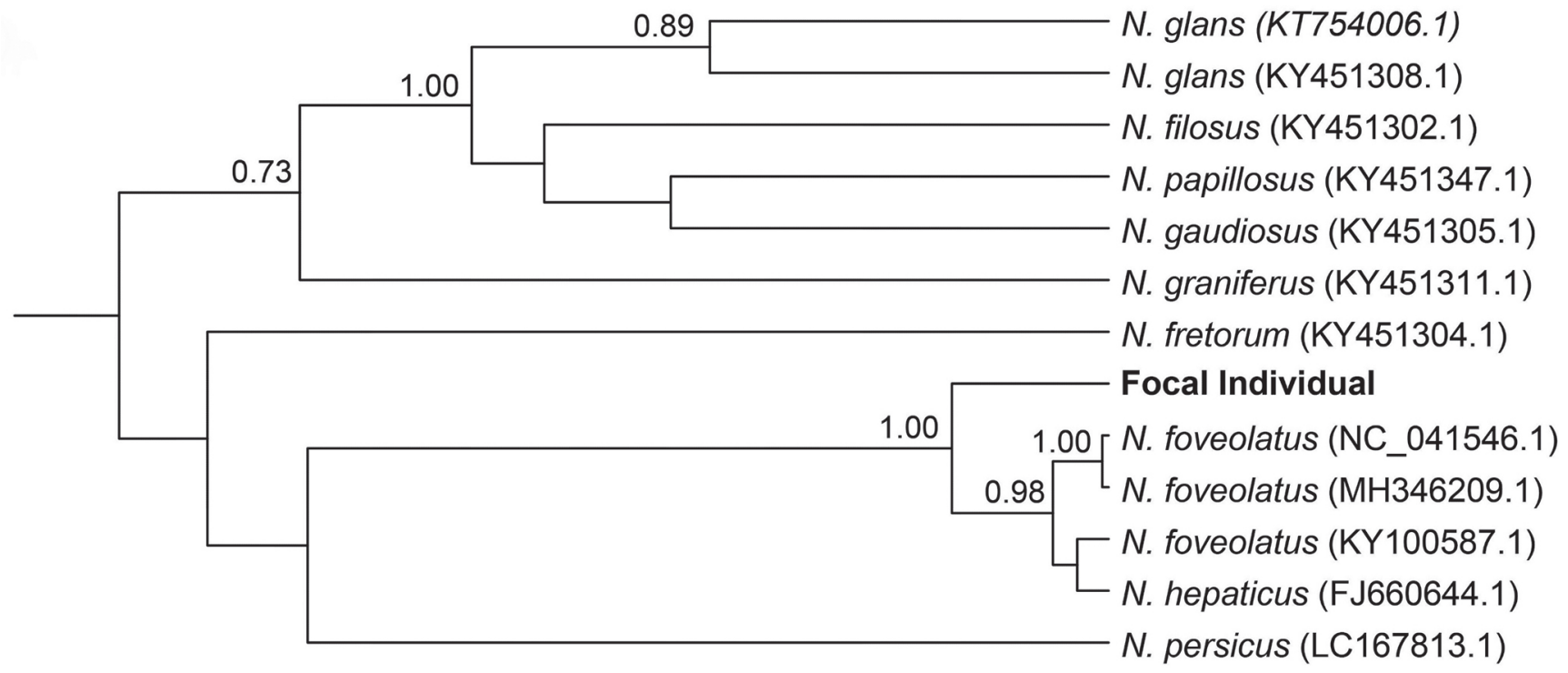

B

0.05

Figure 3. Summarized genetic identification of the focal individual through (A) Neighbor-Joining and (B) Bayesian trees of the COl fragment. Only bootstrap values higher than $70 \%$ (A) and posterior probabilities higher than 0.70 (B) are shown. 
Table 1. Species of Nassarius accessed from GenBank and accession numbers.

\begin{tabular}{|c|c|c|c|c|c|}
\hline Species & Accession number & Species & Accession number & Species & Accession number \\
\hline Antillophos sp. & GU393391.1 & Nassarius foveolatus & NC041546.1 & Nassarius olivaceus & KY451342.1 \\
\hline Nassarius acuminatus & GU393380.1 & Nassarius fraterculus & KX069667.1 & Nassarius olivaceus & MG682443.1 \\
\hline Nassarius acuminatus & KY100533.1 & Nassarius fraudulentus & KY451303.1 & Nassarius olomea & KY451343.1 \\
\hline Nassarius acuminatus & KY451253.1 & Nassarius fretorum & KY451304.1 & Nassarius oneratus & KY451344.1 \\
\hline Nassarius acuticostus & KY100534.1 & Nassarius gaudiosus & KY451305.1 & Nassarius pagodus & FM999173.1 \\
\hline Nassarius acuticostus & KY451254.1 & Nassarius glans & KT754006.1 & Nassarius papillosus & KY451347.1 \\
\hline Nassarius agapetus & KY451255.1 & Nassarius glans & KY451308.1 & Nassarius persicus & LC167813.1 \\
\hline Nassarius albescens & KY499727.1 & Nassarius globosus & KY451306.1 & Nassarius poupini & KY451351.1 \\
\hline Nassarius algidus & KY100535.1 & Nassarius globosus & KY451309.1 & Nassarius pullus & $J Q 975555.1$ \\
\hline Nassarius algidus & KY100536.1 & Nassarius graniferus & KY451311.1 & Nassarius pullus & KY100627.1 \\
\hline Nassarius algidus & GU393388.1 & Nassarius haldemani & KY451313.1 & Nassarius pullus & KY451353.1 \\
\hline Nassarius algidus & GU393389.1 & Nassarius hepaticus & $J Q 975462.1$ & Nassarius radians & KC970054.1 \\
\hline Nassarius arcularia & KY451259.1 & Nassarius hepaticus & FJ660667.1 & Nassarius radians & KC970058.1 \\
\hline Nassarius arcularia & KY451340.1 & Nassarius hepaticus & FJ660644.1 & Nassarius reeveanus & KY451355.1 \\
\hline Nassarius arcus & KY451260.1 & Nassarius herosae & KY451314.1 & Nassarius reticulatus & EF571446.1 \\
\hline Nassarius babylonicus & KY451261.1 & Nassarius hirasei & KY100588.1 & Nassarius reticulatus & KR084688.1 \\
\hline Nassarius barsdelli & KY451262.1 & Nassarius hirasei & KY100589.1 & Nassarius rufus & KY451358.1 \\
\hline Nassarius bellulus & KY451263.1 & Nassarius horridus & KY451240.1 & Nassarius samiae & KY451359.1 \\
\hline Nassarius bicallosus & KY451264.1 & Nassarius houbricki & KC970035.1 & Nassarius semiplicatus & $J 0975563.1$ \\
\hline Nassarius bimaculosus & KY451265.1 & Nassarius houbricki & KC970031.1 & Nassarius semiplicatus & $J Q 975564.1$ \\
\hline Nassarius boucheti & KY451266.1 & Nassarius idyllius & KY451345.1 & Nassarius semisulcatus & KY451360.1 \\
\hline Nassarius callospira & KY451267.1 & Nassarius incrassatus & KT988325.1 & Nassarius sinarus & KX519508.1 \\
\hline Nassarius camelus & KY451268.1 & Nassarius incrassatus & KU714729.1 & Nassarius sinarus & KY100645.1 \\
\hline Nassarius cinctellus & KY451279.1 & Nassarius incrassatus & MG934953.1 & Nassarius sinusigerus & KY451363.1 \\
\hline Nassarius cinnamomeus & KY451280.1 & Nassarius interliratus & KY451316.1 & Nassarius siquijorensis & $J Q 975552.1$ \\
\hline Nassarius concinnus & KY451283.1 & Nassarius irus & KY451317.1 & Nassarius siquijorensis & KP253020.1 \\
\hline Nassarius concinnus & KY451364.1 & Nassarius javanus & KY451318.1 & Nassarius splendidulus & KY451365.1 \\
\hline Nassarius conoidalis & JQ975565.1 & Nassarius kooli & KY451321.1 & Nassarius stigmarius & KY451392.1 \\
\hline Nassarius conoidalis & KY451284.1 & Nassarius kraussianus & EF636006.1 & Nassarius subspinosus & KY451243.1 \\
\hline Nassarius coronatus & KY451287.1 & Nassarius kraussianus & KY451322.1 & Nassarius subtranslucidus & KY451393.1 \\
\hline Nassarius crematus & KY451288.1 & Nassarius labordei & KY451323.1 & Nassarius succinctus & KP253021.1 \\
\hline Nassarius crematus & KY451330.1 & Nassarius leptospirus & KY451324.1 & Nassarius succinctus & $J Q 975500.1$ \\
\hline Nassarius crenoliratus & KY451289.1 & Nassarius limnaeiformis & KY451325.1 & Nassarius succinctus & $J Q 975501.1$ \\
\hline Nassarius cuvierii & JQ950234.1 & Nassarius livescens & $J Q 975514.1$ & Nassarius succinctus & KY100688.1 \\
\hline Nassarius dijki & KY451293.1 & Nassarius livescens & KY100592.1 & Nassarius sufflatus & KT290129.1 \\
\hline Nassarius disparilis & KY451294.1 & Nassarius lochi & KY451326.1 & Nassarius sufflatus & GU393387.1 \\
\hline Nassarius distortus & KY451295.1 & Nassarius luridus & KY451327.1 & Nassarius sufflatus & KY100689.1 \\
\hline Nassarius dorsatus & JQ975553.1 & Nassarius margaritifer & KY451329.1 & Nassarius sufflatus & KY100691.1 \\
\hline Nassarius dorsatus & $J Q 975554.1$ & Nassarius martinezi & KC970050.1 & Nassarius sufflatus & KY100694.1 \\
\hline Nassarius dorsuosus & KY451296.1 & Nassarius mendicus & KX069671.1 & Nassarius tabescens & KY451394.1 \\
\hline Nassarius ecstilbus & KY451297.1 & Nassarius moolenbeeki & KY451332.1 & Nassarius teretiusculus & KY100695.1 \\
\hline Nassarius euglyptus & KX519509.1 & Nassarius multicostatus & KY451333.1 & Nassarius thachi & KX519507.1 \\
\hline Nassarius euglyptus & KY100558.1 & Nassarius multipunctatus & KY451334.1 & Nassarius thachi & KY451395.1 \\
\hline Nassarius euglyptus & KY451299.1 & Nassarius nigrus & KY451241.1 & Nassarius vanpeli & KY451399.1 \\
\hline Nassarius eximius & KY451300.1 & Nassarius nitidus & GU270625.1 & Nassarius vanuatuensis & KC970062.1 \\
\hline Nassarius fenistratus & KY451301.1 & Nassarius nitidus & MG934857.1 & Nassarius velvetosus & KC970064.1 \\
\hline Nassarius festivus & JQ975431.1 & Nassarius nodifer & KY100593.1 & Nassarius velvetosus & KC970063.1 \\
\hline Nassarius festivus & $A B 642676.1$ & Nassarius nodifer & KY100621.1 & Nassarius venustus & KY451400.1 \\
\hline Nassarius filosus & KY451302.1 & Nassarius noguchii & KY451338.1 & Nassarius vibex & KU905981.1 \\
\hline Nassarius foveolatus & KY100587.1 & Nassarius novaezelandiae & KY451339.1 & Nassarius vitiensis & KY451403.1 \\
\hline Nassarius foveolatus & MH346209.1 & Nassarius ocellatus & KY451341.1 & & \\
\hline
\end{tabular}




\section{RESULTS AND DISCUSSION}

As referred above, the specimens of $N$. foveolatus (Fig. 2A-B) were initially collected in Rocio, Paranaguá, Paraná. This locality is adjacent to Dom Pedro II Port (Port of Paranaguá), one of the largest in Brazil, which suggests that the species may have been introduced through ballast water. On the site, there is a small patch of mangrove bordered by a tidal flat with marshes. During low tides the plain is exposed, keeping some pools of water. Inside and around these pools, active live specimens were found at densities of up to 11 individuals $/ \mathrm{m}^{2}$, in sympatry with N. vibex (Say, 1822) (Fig. 2C-D). The native N. vibex can be easily distinguished by being smaller, with the peristome callus much more developed in the adult specimens, by the thicker outer lip, and by the spire sculpture of strong axial ribs.

For the Bay of Bengal, in Odisha state, India, Ghosh et al. (2017) found a density of up to 11.8 individuals/ $\mathrm{m}^{2}$ of $N$. foveolatus, suggesting that the density of this species in the Paranaguá Estuarine Complex is already reaching the same levels as those observed in its natural environment. On June 5, 2019, living individuals of $N$. foveolatus were found in the Emboguaçu River, in the Lamin Island, in Europinha (Vista Bela), and also in Ponta da Pita, all localities in the Paranaguá Estuarine Complex (Fig. 1).

The genetic identification for $N$. foveolatus suggested both by NJ (Fig. 3A) and BI (Fig. 3B) trees is highly supported. Interestingly, a sequence deposited as N. hepaticus (Pulteney, 1799) (FJ660644.1) in GenBank was also assigned to this group. However, since the other sequences of this species were assigned in a distant clade with $N$. nodifer (Powys, 1835) (see Appendices session for the entire phylogeny), this sequence probably represents an error of identification (as both species have similar shells) or even introgression between $N$. hepaticus and N. foveolatus, process already proposed for other Nassarius species (for details, see $\mathrm{Pu}$ et al., 2017).

Despite the inference of ballast water as responsible for the artificial dispersal of $N$. foveolatus in Paranaguá Estuarine Complex, the confirmation of this via of dispersal must be verified by additional studies. These could serve as alert on the species worldwide. The event can be the tip of the iceberg, representing a wide range of invasive species in the region (e.g., Rocha \& Kremer, 2005; Neves \& Rocha, 2008; Lopes, 2009; Altvater \& Coutinho, 2015).

Based only on the collection experience, it is already possible to infer that the specimens of $N$. foveolatus occur side by side with the native specimens of $N$. vibex, having the same niche. As previously only N. vibex existed in that place (Rios, 2009; Absher et al., 2015), at least a displacement of the native species has occurred. However, more ecological studies may certainly confirm this displacement and additional consequences in the local ecosystem, as nassariids can be predators and scavengers. Control procedures should be also greatly implemented.

\section{ACKNOWLEDGEMENTS}

We thank Esther Valentina da Veiga de Vasconcellos Gernet who collected the first specimens of $N$. foveolatus on the coast of Paraná state, two anonymous reviewers for their valuable comments in the manuscript, and Desyrêe Mathiew Teixeira Delgado for her help to edit Fig. 2.

\section{REFERENCES}

Abbate, D. \& Cavallari, D.C. 2013. A new species of Nassarius (Gastropoda, Nassariidae) from Canopus bank, off Northeast Brazil. Papéis Avulsos de Zoologia, 53(1): 1-4.

Absher, T.M.; Ferreira Junior, A.L. \& Christo, S.W. 2015. Conchas de Moluscos Marinhos do Paraná. Rio de Janeiro, Publiki. 20p.

Altvater, L. \& Coutinho, R. 2015. Colonisation, competitive ability and influence of Stragulum bicolor van Ofwegen and Haddad, 2011 (Cnidaria, Anthozoa) on the fouling community in Paranaguá Bay, Southern Brazil. Journal of Experimental Marine Biology and Ecology, 465: 55-61.

Bachelet, G.; Simon-Bouhet, B.; Desclaux, C.; Garcia-Meunier, P.; Mairesse, G.; Montaudouin, X.; Raigné, H.; Randriambao, K.; Sauriau, P.-G. \& Viard, F. 2004. Invasion of the eastern Bay of Biscay by the nassariid gastropod Cyclope neritea: origin and effects on resident fauna. Marine Ecology Progress Series, 276: 147-159.

Brown, A.C. 1982. The biology of sandy-beach whelks of the genus Bullia (Nassariidae). Oceanography and Marine Biology, Annual Review, 20: 309-361.

Carlton, J.T. 1992. Introduced marine and estuarine mollusks of North America: An end-of-the-20th-century perspective. Journal of Shellfish Research, 11(2): 489-505.

Carlton, J.T. 1996. Biological invasion and cryptogenic species. Ecology, 77(6): 1653-1655.

Cavallari, D.C. \& Abbate, D. 2013. New records and distribution extension of Nassarius karinae Usticke, 1971 (Mollusca: Gastropoda: Nassariidae) in the SW Atlantic. Check List, 9(6): 1533-1535.

Cernohorsky, W.0. 1984. Systematics of the family Nassariidae (Mollusca: Gastropoda). Bulletin of the Auckland Institute and Museum, 14: 1-356.

Darriba, D.; Taboada, G.L.; Doallo, R. \& Posada, D. 2012. jModelTest 2: more models, new heuristics and parallel computing. Nature Methods, 9(8): 772.

Drummond, A.J.; Suchard, M.A.; Xie, D. \& Rambaut, A. 2012. Bayesian phylogenetics with BEAUti and the BEAST 1.7. Molecular Biology and Evolution, 29(8): 1969-1973.

Edgar, R.C. 2004. MUSCLE: multiple sequence alignment with high accuracy and high throughput. Nucleic Acids Researsh, 32(5): 1792-1797.

Ferreira, C.E.L.; Gonçalves, J.E.A. \& Coutinho, R. 2004. Cascos de navios e plataformas como vetores na introdução de espécies exóticas. In: Silva, J.S.V. \& Souza, R.C.C.L. Água de lastro e bioinvasão. Rio de Janeiro, Interciência, p. 143-156.

Fofonoff, P.W.; Ruiz, G.M.; Steves, B.; Simkanin, C. \& Carlton, J.T. 2018. National Exotic Marine and Estuarine Species Information System. Available at: http://invasions.si.edu/nemesis. Access in: 01/07/2019.

Folmer, 0.; Black, M.; Hoeh, W.; Lutz, R. \& Vrijenhoek, R. 1994. DNA primers for amplification of mitochondrial cytochrome $c$ oxidase subunit I from diverse metazoan invertebrates. Molecular Marine Biology and Biotechnology, 3(5): 294-299.

Galindo, L.A.; Puillandre, N.; Utge, J.; Lozouet, P. \& Bouchet, P. 2016. The phylogeny and systematics of the Nassariidae revisited (Gastropoda, Buccinoidea). Molecular Phylogenetics and Evolution, 99: 337-353. 
Ghosh, A.; Tripathy, B. \& Mukhopadhyay, A. 2017. Ecology of two sympatric Nassariid gastropods [Nassarius (Niotha) stolatus (Gmelin) and Nassarius (Zeuxis) foveolatus (Dunker)] along the northern east coast of India. Indian Journal of Geo Marine Sciences, 46(1): 93-101.

Goka, K. 2019. Invasive Species of Japan: Nassarius sinarus. Available at: https://www.nies.go.jp/biodiversity/invasive/DB/detail/70470e.html. Access in: 01/07/2019.

Hebert, P.D.N.; Cywinska, A.; Ball, S.L. \& deWaard, J.R. 2003. Biological identifications through DNA barcodes. Proceeding of the Royal Society of London, 270(1512): 313-321.

Lopes, R.M. (Ed.). 2009. Informe sobre as espécies exóticas invasoras marinhas no Brasil. Brasília, Ministério do Meio Ambiente. 441p. (Biodiversidade 33)

Mahapatro, D.; Panigrahy, R.; Panda, S. \& Mishra, R.K. 2018. Malcofaunal diversity of Chilika Lake, Odisha, India. Proceedings of the Zoological Society, 71(3): 272-280.

Nekhaev, I.0. 2014. Marine shell-bearing Gastropoda of Murman (Barents Sea): an annotated check-list. Ruthenica, 24(2): 75-121.

Neves, C.S. \& Rocha, R.M. 2008. Introduced and cryptogenic species and their management in Paranaguá Bay, Brazil. Brazilian Archives of Biology and Technology, 51(3): 623-633.

Pu, C.; Li, H.; Zhu, A.; Chen, Y.; Zhao, Y. \& Zhan, A. 2017. Phylogeography in Nassarius mud snails: complex patterns in congeneric species. PLOS ONE, 12(7): e0180728.

Raut, D.; Ganesh, T.; Murty, N.V.S.S. \& Raman, A.V. 2005. Macrobenthos of Kakinada Bay in the Godavari delta, East coast of India: comparing decadal changes. Estuarine, Coastal and Shelf Science, 62(4): 609-620.

Rios, E.C. 2009. Compendium of Brazilian Sea Shells. Rio Grande, Evangraf. $668 \mathrm{p}$.

Robba, E.; Di Geronimo, I.; Chaimanee, N.; Negri, M.P. \& Sanfilippo, R. 2007. Holocene and recent shallow soft-bottom mollusks from the Western Gulf of Thailand: Pak Phanang Bay and additions to Phetchaburi fauna. Bolletino Malacologico, 43(n. special): 1-98.

Rocha, R.M. \& Kremer, L.P. 2005. Introduced ascidians in Paranaguá Bay, Paraná, southern Brazil. Revista Brasileira de Zoologia, 22(4): 1170-1184.

Rosenberg, G. 2006. OBIS Indo-Pacific Molluscan Datase. Available at: http:// clade.ansp.org/obis/search.php/region3078. Access in: 20/05/2019.
Rosenberg, G. 2009. Malacolog 4.1.1: A Database of Western Atlantic Marine Mollusca. Available at: http://www.malacolog.org. Access in: 24/04/2019.

Silva, E.C. \& Barros, F. 2011. Macrofauna bentônica introduzida no Brasil: lista de espécies marinhas e dulcícolas e distribuição atual. Oecologia Australis, 15(2): 326-344.

Souza, R.C.C.L.; Calazans, S.H. \& Silva, E.P. 2009. Impacto das espécies invasoras no ambiente aquático. Ciência e Cultura, 61(1): 35-41.

Stachowicz, J.J., Whitlatch, R.B. \& Osman, R.W. 1999. Species diversity and invasion resistance in a marine ecosystem. Science, 286(5444): 1577-1579.

Subba Rao, N.V.; Dey, A \& Barua, S. 1992. Estuarine and marine molluscs. In: Government of India. Fauna of West Bengal. Mollusca. Calcutta, Zoological Survey of India. part 9, p. 129-268.

Tallmark, B. 1980. Population dynamics of Nassarius reticulates (Gastropoda: Prosobranchia) in Gullmar Fjord, Sweden. Marine Ecology Progress Series, 3:51-62.

Tamura, K. \& Nei, M. 1993. Estimation of the number of nucleotide substitutions in the control region of mitochondrial DNA in humans and chimpanzees. Molecular Biology and Evolution, 10(3): 512-526.

Tan, S.K. \& Woo, H.P.M. 2010. A preliminary checklist of the molluscs of Singapore. Singapore, Raffles Museum of Biodiversity Research. 82p.

Taylor, J.D.; Morris, N.J. \& Taylor, C.N. 1980. Food specialization and the evolution of predatory prosobranch gastropods. Palaentology, 23(2): 375-409.

Townsend, M.; Marshall, B.A. \& Greenfield, B.L. 2010. First records of the Australian dog whelk, Nassarius (Plicarcularia) burchardi (Dunker in Philippi, 1849) (Mollusca: Gastropoda) from New Zealand. New Zealand Journal of Marine and Freshwater Research, 44(4): 343-348.

Van Dingenen, F.; Ceulemans, L.; Landau, B.M. \& Silva, C.M. 2015. The family Nassariidae (Gastropoda: Buccinoidea) from the late Neogene of northwestern France. Cainozoic Research, 15(1-2): 75-122.

Zhang, S.-P. \& Yang, J.-W. 2010. Revision of species names of several Nassarius in China seas. Oceanologia et Limnologia Sinica, 41(5): 791-795. 


\section{APPENDIX 1}

Neighbor-Joining tree of the $\mathrm{COI}$ gene with all Nassarius sequences analyzed for genetic identification of the focal individual. Numbers in the nodes represent bootstrap values.

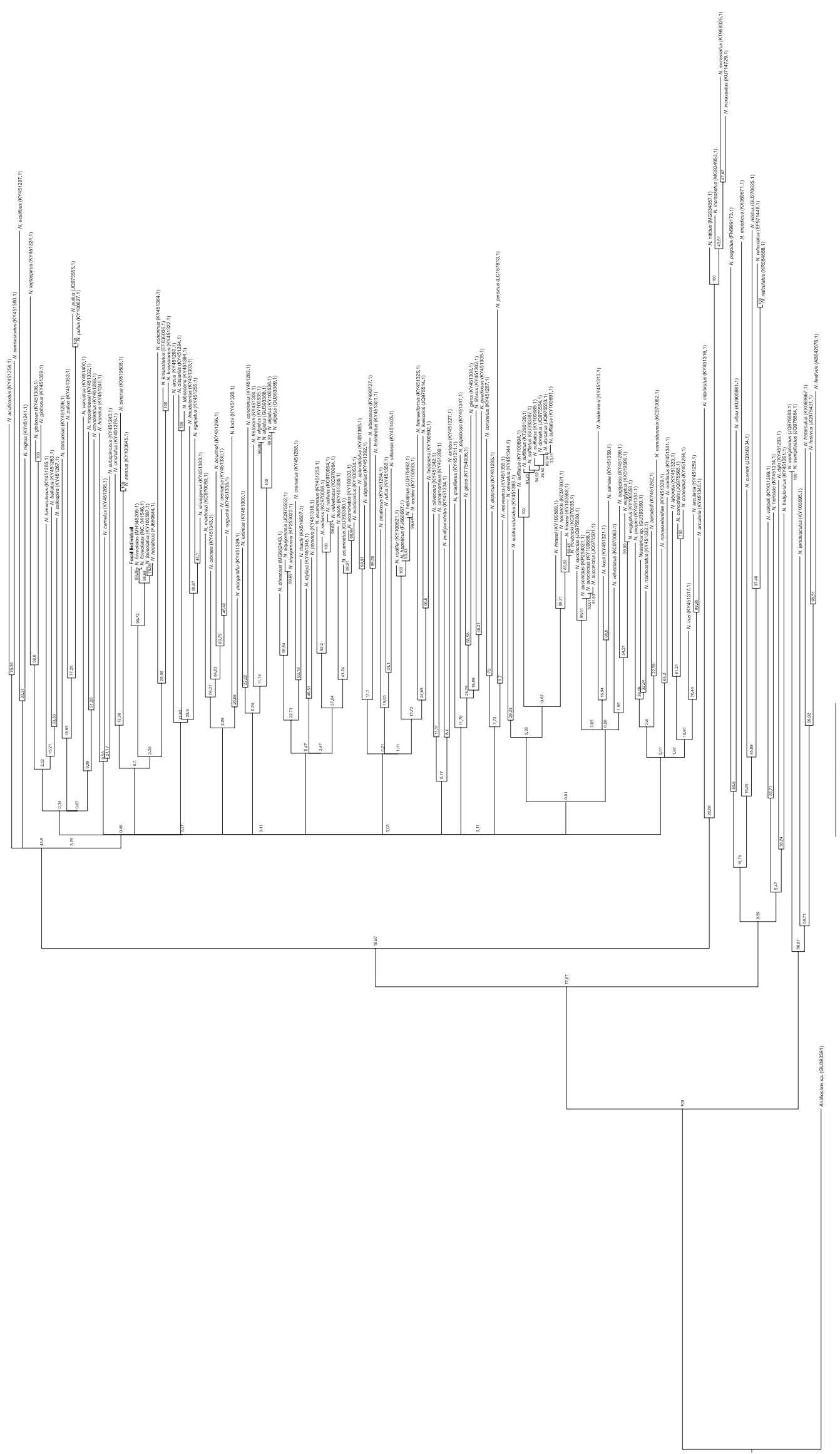


APPENDIX 2

Bayesian tree of the $\mathrm{COI}$ gene with all Nassarius sequences analyzed for genetic identification of the focal individual. Numbers in the nodes represent posterior probabilities.

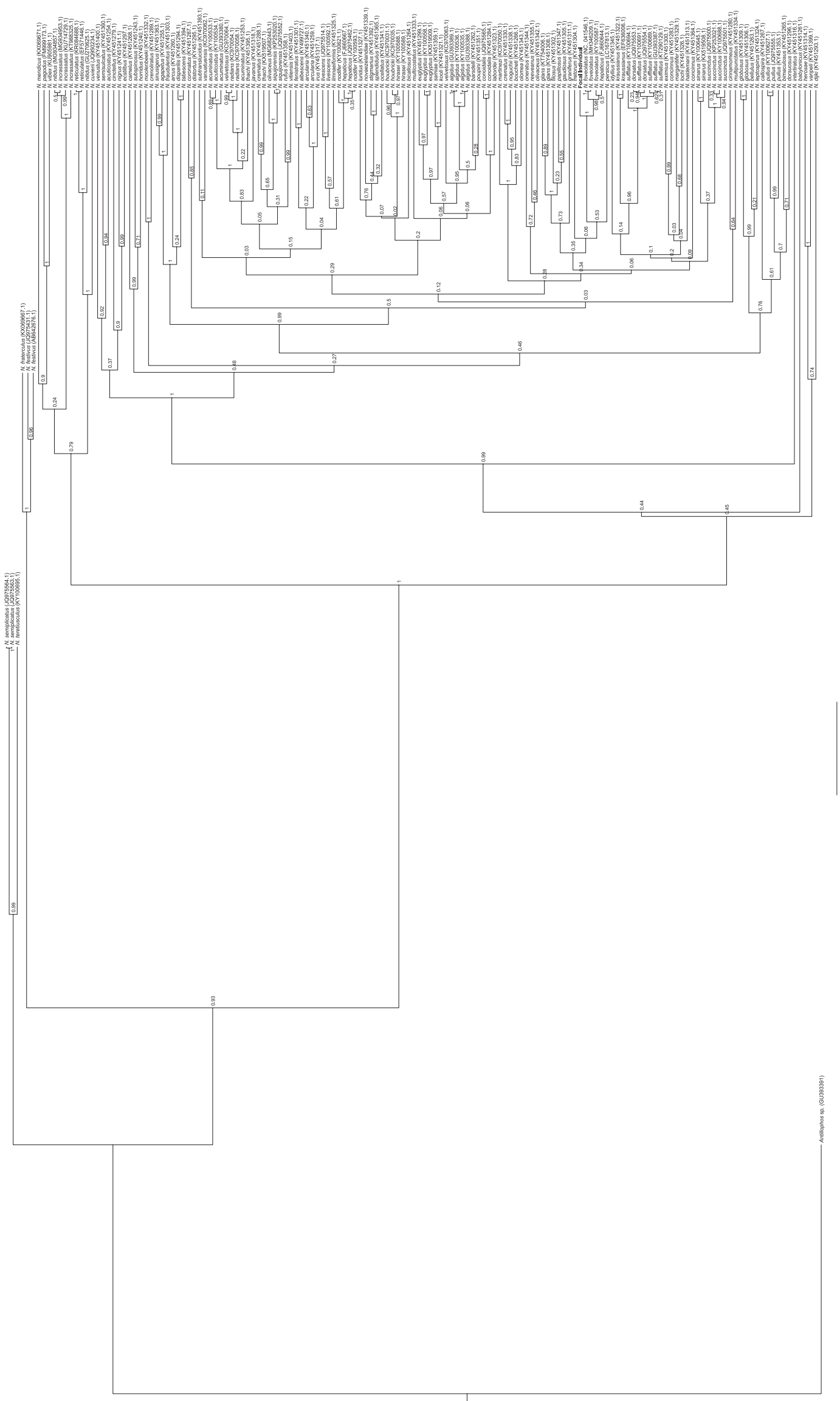

